\title{
The Serum Level of CD16 + 56 in Zona
}

\author{
Nguyễn Lan Anh1, Bùi Thị Vân1', Vũ Thu Trang1, Đặng Trung Thành'1, Nguyễn Thị Quỳnh Trang1, \\ Nguyễn Thị Tuấn², Đặng Văn Em¹
}

\author{
${ }^{1}$ Department of Dermatology, Venereology Allergy, 108 Military Central Hospital, Ha Noi, Vietnam \\ ${ }^{2}$ Department of Immunology, 108 Military Central Hospital, Ha Noi, Vietnam \\ Email: xtamhuynh@yahoo.com
}

How to cite this paper: Anh, N.L., Vân, B.T., Trang, V.T., Thành, Đ.T., Trang, N.T.Q., Tuấn, N.T. and Em, Đ.V. (2021) The Serum Level of CD16 + 56 in Zona. Journal of Cosmetics, Dermatological Sciences and Applications, 11, 1-9.

https://doi.org/10.4236/jcdsa.2021.111001

Received: November 30, 2020

Accepted: March 1, 2021

Published: March 4, 2021

Copyright $\odot 2021$ by author(s) and Scientific Research Publishing Inc. This work is licensed under the Creative Commons Attribution International License (CC BY 4.0).

http://creativecommons.org/licenses/by/4.0/

\begin{abstract}
Objectives: To study the change of CD16 + 56 in zona. Materials and Methods: 62 zona patients admitted at Inpatient Department of Dermatology, Venereology Allergy, 108 Military Central Hospital, and 30 healthy volunteers who were matched for age and sex participated in this study. Prospective, cross-sectional study with controls was conducted. We measured the number of CD16 + CD56 by flow cytometry using FACS Callibur. Results: The mean level of CD16 + 56 in zona patients was $253 \pm 200(106$ cells/l), which was lower than that of control group but then increased after treatment. The change of CD16 + 56 did not correlate with patients' age. Patients who were in severe condition or had affected size from $3 \%$ or more had a lower number of CD16 + 56 than control group. Conclusion: The number of $\mathrm{CD} 16+56$ in zona patients were lower than that of healthy people.
\end{abstract}

\section{Keywords \\ CD16 + 56, Zona}

\section{Open Access}

\section{Introduction}

Zona is a common disease caused by an epidermotropic and neurotropic virus named Varicella Zoster virus (VZV). All ages and both sexes can develop zona but the age of peak incidence is from 50 or more. In immunocompromised patients, a higher rate of infection and a more severe course of disease are seen [1]. Prolonged sequela is a burden for patients' quality of life.

NK cell has a diameter reaching $12-15 \mu \mathrm{m}$, which is larger than B cell and T cell. It is produced and differentiated in bone marrow and accounts for 5\% - 10\% of all monocytes in peripheral blood. Main surface markers are CD2, CD16, CD45, CD56, CD57, CD11a/CD18, CD11b/CD18 and CD11c/CD18. NK cell is distinguished from other monocytes by the presence of CD16 and CD56 [2]. The 
development of NK cells depends on the interaction between their progenitors and bone-marrow stromal cells, under the effect of cytokines such as IL-15, Flt3 ligand and stem-cell factor [3].

The critical function of NK cell is destroying cells with pathogenous antigens such as cancer or virus-infected cells. They secret cytokines such as IFN- $\gamma$, TNF$\alpha$, and interleukin (IL)-10 ... First response of host under invasion of VZV is the activation of NK cell against viruses when they penetrate the mucosal barrier and launch adaptive immune response [4]. There were some studies on the role of NK cells in confining the inflammatory process caused by Herpes viruses [5]. Counting the number of CD16 + 56 can evaluate the change of NK cell.

It is surprising that there has been little study on the interaction between VZV and NK cells to demonstrate the involvement of them in VZV pathogenesis. A research of Mireille T. M. Vossen et al. on 5 severe herpes zoster children found that NK cells are decreased in acute phase but restored during convalescence [3]. Some studies also indicated the decline in NK cells can make the Herpes infection worse, even cause fatality [6]. These reports confirm the association of NK cells during VZV infection. However, to the best of our knowledge, it has not been investigated whether NK cells play an important part in the infection of VZV. Subsequent reports were able to identify the role of VZV-infected lymphocytes in viremia. However, the third major lymphocyte population in peripheral blood-natural killer (NK) cells has never been identified adequately due to the delayed development of the NK cell field in comparison to our understanding of $\mathrm{T}$ cell and B cell immunology. Moreover, there is a limitation in number of scientific investigations on the role of NK cells under reactivation of VZV in zona. For that reason, we conducted this study with the objective to measure the change of CD16 + 56 in zona so as to progress our understanding of immune interactions during VZV reactivation.

\section{Materials and Methods}

\subsection{Materials}

- The study group: 62 zona patients admitted at Inpatient Department of Dermatology, Venereology Allergy, 108 Military Central Hospital from 6/2015$6 / 2018$.

Inclusion criteria:

Moderate and severe zona patients, older than 18 years old, present $\leq 5$ days after the onset of skin symptoms, not using any medication such as corticoid or zona treatment drugs, having normal immune system, HIV/AIDS (-), no contraindication for the drugs used in this study, can follow treatment procedures and agree to participate in our research.

Exclusion criteria: patients are not qualified according to inclusion criteria, do not agree to participate in the study or cannot follow treatment procedures.

- Control groups: 30 healthy people came for periodic health examination in 108 Military Central Hospital, having no disease relating immunity or der- 
matology. The age and sex were matched with patients group.

Some criteria in this research:

- Palm code of Blokhin and Glumov: 1 palm of patient corresponds to $1 \%$ body surface area (BSA) [7] [8].

- Likert scale [9] (See Table 1).

- Severity classification:

Mild: affected area: $<1 \%$ BSA; Likert $\leq 4$; no swollen regional lymph nodes; no injured peripheral nerves; sleep disorder: mild; general symptoms: no fever, no malaise.

Moderate: affected area: $1 \%-2 \%$ BSA; Likert: 5 - 6; swollen regional lymph nodes might present or not; no injured peripheral nerves; sleep disorder: mild; general symptoms: no fever, malaise might present or not.

Severe: affected area $\geq 2 \%$ BSA; Likert $\geq 7$; swollen regional lymph nodes might present; injured peripheral nerves might present; sleep disorder: severe; general symptoms: fever might present or not.

\subsection{Methods}

Study design: prospective, cross-sectional study with controls.

\section{Steps:}

- Study group: collecting first blood sample (before treatment) to count the number of $\mathrm{CD} 16+56$ by flow cytometry using FACS Callibur (Becton Dickinson-America).

Collecting second blood sample (after day 20 of treatment) to count the number of CD16 + 56 .

- Control group: collecting blood sample only one time to count the number of $\mathrm{CD} 16+56$

Data analysis: Data was analyzed by using SPSS software statistical computer package version 18. For quantitative data Student's t-test was used and the means and standard deviation were calculated. P-value less than 0.05 was considered significant.

\section{Results (Tables 2-9)}

Table 1. Likert scale to evaluate pain intensity.

\begin{tabular}{ccc}
\hline Pain intensity & By verbal expression & By nonverbal expression \\
\hline 0 & No pain & No expression on the face \\
$1-2$ & Mild pain & Stressful appearance \\
$3-4$ & Moderate pain & Frowning appearance \\
$5-6$ & Severe pain & Groaning, moaning \\
$7-8$ & Very severe pain & Crying \\
$9-10$ & Worst pain possible & Miserable pain \\
\hline
\end{tabular}


Table 2. Clinical characteristics of study group $(n=62)$.

\begin{tabular}{cccc}
\hline \multicolumn{2}{c}{ Clinical characteristics } & Number (n) & $\%$ \\
\hline \multirow{2}{*}{ Gender } & Male & 40 & 64.5 \\
& Female & 22 & 35.5 \\
\multirow{2}{*}{ Age } & $<50$ & 4 & 6.5 \\
& $50-69$ & 36 & 58 \\
\multirow{2}{*}{ Disease severity } & $\geq 70$ & 22 & 35.5 \\
& Moderate & 23 & 37.1 \\
Affected area & Severe & 39 & 62.9 \\
& $\leq 1 \%$ BSA & 23 & 37.1 \\
& $1 \%$ - 2\% BSA & 27 & 43.5 \\
\hline
\end{tabular}

Note: Male had a higher proportion than female and severe patients outweighed mild ones.

Table 3. The correlation between the number of CD16 + 56 (before treatment) and age ( $\mathrm{n}$ $=62$ ).

\begin{tabular}{cccc}
\hline Age & $\begin{array}{c}<0(1) \\
(\mathrm{n}=4)\end{array}$ & $\begin{array}{c}50-69(2) \\
(\mathrm{n}=36)\end{array}$ & $\begin{array}{c}\geq 70(3) \\
(\mathrm{n}=22)\end{array}$ \\
\hline $\mathrm{CD} 16+56\left(10^{6}\right.$ cells $\left./ \mathrm{l}\right)$ & $244 \pm 138$ & $264 \pm 224$ & $231 \pm 171$ \\
$\mathrm{p}$ & & $\mathrm{p}_{1-2}>0.05 ; \mathrm{p}_{1-3}>0.05 ; \mathrm{p}_{2-3}>0.05$ & \\
\hline
\end{tabular}

Note: There was no significant difference in the number of CD16 +56 between three age groups $(\mathrm{p}>0.05)$. $\mathrm{p}_{1-2}$ : The difference between group with age $<50$ and group with age from 50 to 69 (See Table 2); $\mathrm{p}_{1-3}:$ The difference between group with age $<50$ and group with age $\geq 70$ (See Table 3); $\mathrm{p}_{2-3}$ : The difference between group with age from 50 to 69 and group with age $\geq 70$ (See Table 4).

Table 4. Characteristics of 2 groups.

\begin{tabular}{cccc}
\hline Indexes & $\begin{array}{c}\text { Study group } \\
(\mathrm{n}=62)\end{array}$ & $\begin{array}{c}\text { Control group } \\
(\mathrm{n}=30)\end{array}$ & $\mathrm{p}$ \\
\hline Gender Male & 40 & 25 & $>0.05$ \\
Female & 22 & 5 & $>0.05$ \\
Mean age & $58.9 \pm 9.1$ & $57.0 \pm 11.4$ & $>0.4$ \\
\hline
\end{tabular}

Note: There was insignificantly different in gender and mean age of two groups ( $\mathrm{p}>0.05)$.

Table 5. The comparison in the number of CD16 +56 between 2 groups.

\begin{tabular}{cccc}
\hline Group & $\begin{array}{c}\text { Study } \\
(\mathrm{n}=62)\end{array}$ & $\begin{array}{c}\text { Control } \\
(\mathrm{n}=30)\end{array}$ & $\mathrm{p}$ \\
\hline $\mathrm{CD} 16+56\left(10^{6}\right.$ cells $\left./ \mathrm{l}\right)$ & $253 \pm 200$ & $458 \pm 329$ & $<0.05$ \\
\hline
\end{tabular}

Note: The number of CD16 + 56 in study group were significantly lower than that of control group (p < 0.05) (See Table 5)

Table 6. The comparison in the number of CD16 + 56 between moderate, severe and control groups.

\begin{tabular}{cccc}
\hline Severity & $\begin{array}{c}\text { Moderate }(1) \\
(\mathrm{n}=23)\end{array}$ & $\begin{array}{c}\text { Severe }(2) \\
(\mathrm{n}=39)\end{array}$ & $\begin{array}{c}\text { Control (3) } \\
(\mathrm{n}=30)\end{array}$ \\
\hline $\mathrm{CD} 16+56\left(10^{6}\right.$ cells $\left./ \mathrm{l}\right)$ & $302 \pm 200$ & $224 \pm 196$ & $458 \pm 329$ \\
$\mathrm{p}$ & & $\mathrm{p}_{1-2}>0.05 ; \mathrm{p}_{1-3}>0.05 ; \mathrm{p}_{2-3}<0.05$ & \\
\hline
\end{tabular}

Note: The number of CD16 + 56 in severe patients were significantly lower than that in healthy volunteers $(\mathrm{p}<0.05)($ See Table 6). 
Table 7. The comparison in the number of $\mathrm{CD} 16+56$ between patient groups with different affected areas and control group.

\begin{tabular}{ccccc}
\hline Groups & \multicolumn{5}{c}{$\begin{array}{c}\text { Study } \\
(\mathrm{n}=63)\end{array}$} & $\begin{array}{c}\text { Control }(\mathrm{n}=30) \\
(4)\end{array}$ \\
\hline \multirow{3}{*}{ Affected area } & $\leq 1 \%$ & $1 \%-2 \%$ & $\geq 3 \%$ & \\
& $(\mathrm{n}=23)$ & $(\mathrm{n}=27)$ & $(\mathrm{n}=12)$ & \\
$\mathrm{CD} 16+56\left(10^{6}\right.$ cells $\left./ \mathrm{l}\right)$ & $241 \pm 128$ & $297 \pm 258$ & $177 \pm 140$ & $458 \pm 329$ \\
& & $\mathrm{p}_{1-2}>0.05, \mathrm{p}_{2-3}>0.05, \mathrm{p}_{1-3}>0.05$ & \\
$\mathrm{p}$ & & $\mathrm{p}_{1-4}<0.05 ; \mathrm{p}_{2-4}>0.05 ; \mathrm{p}_{3-4}<0.05$ & \\
\hline
\end{tabular}

Note: No significant difference in the number of CD16 +56 between groups with different affected area ( $p>0.05)$. However, the number of $\mathrm{CD} 16+56$ in patients with influenced acreage from $3 \%$ or more were lowest in three groups and significantly lower than that of control (See Table 7).

Table 8. The change in cellular immunity in patient group before and after treatment ( $\mathrm{n}$ $=62)$.

\begin{tabular}{cccc}
\hline Treatment & Before & After & p \\
\hline $\mathrm{CD} 16+56\left(10^{6} \mathrm{cells} / \mathrm{l}\right)$ & $253 \pm 200$ & $362 \pm 311$ & $<0.05$ \\
\hline
\end{tabular}

Notes: after treatment, the number of CD16 + 56 were significantly increased $(\mathrm{p}<0.05)$ (See Table 8$)$.

Table 9. The comparison in the number of CD16 + 56 between patient group (after treatment) and control group.

\begin{tabular}{cccc}
\hline Groups & $\begin{array}{c}\text { Study } \\
(\mathrm{n}=62)\end{array}$ & $\begin{array}{c}\text { Controls } \\
(\mathrm{n}=30)\end{array}$ & $\mathrm{p}$ \\
\hline $\mathrm{CD} 16+56\left(10^{6}\right.$ cells $\left./ \mathrm{l}\right)$ & $362 \pm 311$ & $458 \pm 329$ & $>0.05$ \\
\hline
\end{tabular}

Note: After treatment, no significant difference was observed between study group and control (See Table 9).

\section{Discussion}

In 62 zona patients, the percentage of male was larger than that of female, because this study was operated in Inpatient Department of Dermatology, Venereology Allergy, 108 Military Central Hospital in which more male patients visit annually. Patients in 50 - 69 years old took the largest proportion and there were more severe patients than moderate ones, which are demonstrated in Table 2.

NK cells secret cytokines like IFN- $\gamma$, TNF- $\alpha$, IL-1, IL-3. Unlike T lymphocytes, NK cells under stimulation can produce cytokines fast and effectively, which is the reason why they play an important role in immune response at an early stage. The response process of NK cells has 4 phases: 1 -activating inactive NK cells under impact of cytokines like IL-2, IL-7, IL-12 and interferon (IF) $\alpha, \beta, \gamma$; 2 -rising in number in both peripheral blood and bone marrow; 3-local accumulation by the role of inositol phosphates and increased intracellular calcium(activated Phospholipase A2 and arachidonic acid have a key role in activating NK cells); 4-cellular lysis due to particles in cytoplasm containing protease, nucleases and perforin. These substances make holes on target cell membrane, leading to the change in ions entering the cells, which in turn makes them swelling and lysing. Moreover, some studies demonstrate that lifelong NK cells 
with immunological memory can contribute to immunity in fighting against Herpes reinfection [10]. In varicella children, the activity of NK cells was enhanced in places where VZV intruded and higher than that of healthy ones. Immunocompromised children with zona had a decreased activity of NK cell in the first 3 days and then escalated in recovery period [5]. When counting the number of immune cells in a 2-year-old girl died from varicella, Etzioni discovered that the number of $\mathrm{T}$ and $\mathrm{B}$ lymphocyte were normal but the NK cells' activity was dropped.

Some researches prove the capacity of NK cells in restraining the infection of Herpes viruses such as VZV, HSV-1, CMV, HBV, HCV and HIV. Many strains of virus, including Herpes viruses, can cut down on the cell surface expression of MHC class I, which in turn can diminish the ability of CD8 + T lymphocytes in recognizing and destroying infected cells. Moreover, virus can provoke cellular stress responses, leading to upregulation of ligands activating some NK cell's surface receptors like Natural Killer Group 2D (NKG2D) and DNAM-1 which are fundamental for it to identify and eliminate cells containing viruses [6]. According to Chelsea Gerada et al., NK cells played a central role in immune response against VZV [11]. There are 3 reasons for this statement. The first one is that in a research on severe, life-threatening varicella patients, NK cells were nearly absent in circulation during the early phase of infection but returned to normal during restoration phase, which is explained by the concentration of these cells in skin lesions and the ongoing infection leading to exhaustion of NK cells [3]. The second explanation is that when injecting antigens of VZV in the skin of healthy people who used to be infected, NK cells are rapidly recruited to the infected site. Last but not least, in some in vitro experiments, VZV infected cells become more sensitive to granulysin-a cytotoxic molecule manufactured by NK cells [11]. The activity of NK cells relies on perforin and granzyme. The function of NK cells in exterminating VZV infected cells through CD16 Fc receptor and cytokines they secrete, mainly interferon [12].

However, VZV has many mechanisms to slow down and suppress NK cells. First, activated VZV can penetrate the host immune system and limit the activity of NK cells by decreasing the expression of ligands binding NKG2D-a receptor activating NK cells [13]. Second, VZV can retain and increase NK cell-inhibitory signals. Moreover, there are some other strategies such as inhibiting the expression of TRAIL death receptor in infected cells which is necessary for the NK cell's TRAIL-induced apoptosis, interfering with NK cells migration or the genesis of an immunological synapse helping NK cells recognize and kill infected host cells [6]. Cauda realized in the first week of disease, activity of NK cells is slowed down due to virus reactivation but higher than that of controls in the second week [14]. Some researches indicated a reduction in IFN- $\gamma$ production from VZV infected NK cells, which is an important cytokine restraining the replication of viruses. Furthermore, VZV can manipulate the downstream signals after IFN- $\gamma$ binds its receptor [10]. The study of Choon Kwan Kim also demon- 
strated the level of IFN- $\gamma$ in zona patients is lower than that of healthy controls, reflecting the attenuation in function of NK cells [11].

In our study, the number of CD16 + 56 were indifferent between 3 groups of age, although patients $>70$ years old had the lowest quantity (Table 3 ), which is suitable to the explanation in which immune response is weakened through age.

The amount of CD16 + 56 in zona patients were lower than that of controls (Table 5), and after 20 days of treatment, they increased significantly (Table 8), which was equivalent to control group (Table 9), meaning that after our therapy, the volume of CD16 + 56 returned to normal. No significant difference was observed between study group and control group in gender and age (Table 4), which means that these biases were excluded. This result was supported by the research of James Barton and Ihara T. who assumed that the number and activity of NK cells declines in the acute phase, rises in recovery phase and restores to ordinary level when patients are completely cured [2] [15].

According to severity, the number of CD16 + 56 in severe patients were lower than that of moderate ones, and significantly below the level of controls (Table 6), showing that severe zona patients had a decrease in the quantity of these cells in comparison to healthy people.

We also assessed the relationship between CD16 + 56 and affected area. Studying on 44 zona patients, Choon Kwan Kim supposed the activity of NK cells in zona patients with influenced average $>20 \mathrm{~cm}^{2}$ is lower than that of control group by measuring the level of IFN- $\gamma$ secreted by NK cells. The lower concentration of IFN- $\gamma$ is, the more widespread skin lesions are [13]. However, our research was not in favor of this study (Table 7). No significant difference was found between three groups with distinct affected area. Nonetheless, the number of $\mathrm{CD} 16+56$ in patients with involved surface area being from $3 \%$ or more were lowest, even lower than that of controls, showing that patients with diffused cutaneous lesions had a lower CD16 + 56 quantity than normal ones. Our results are compatible to the outcome of Tessa Mollie Campbell et al. In this research, there is an increment in expression of chemokine receptors on the surface of NK cells such as C-C Motif Chemokine Receptor 4 (CCR4) and cutaneous lymphocyte antigen (CLA) which are skin-homing receptors. Thanks to those presentations, VZV infected NK cells can migrate to the skin where highly infectious lesions can develop and spread the viruses, resulting to a decline of NK cells in circulation. So theoretically, the more skin lesions appear, the more NK cells in blood sample alleviated [16].

Our research had some limitations. We did not count the number of CD16 + 56 in patients before infection, so the measurement of change in quantity of these cells was not objective. We also evaluated the severity of zona basing on some criteria: affected area, pain intensity (Table 1), symptoms, ... which is not mentioned in domestic or international documents for zona, making our results relative. 


\section{Conclusions}

After studying on 62 zona patients and 30 healthy volunteers, we draw some conclusions:

In zona patients, the number of CD16 + 56 were lesser than that of controls and recovered after treatment.

The change in the concentration of CD16 + 56 was independent of patients' age.

Patients who were in severe condition or had affected size from $3 \%$ or more had a lower level of CD16 + 56 than control group. No significant difference was observed in other groups.

\section{Conflicts of Interest}

The authors declare no conflicts of interest regarding the publication of this paper.

\section{References}

[1] Chu, A.T. (2004) Studying the Clinical and Subclinical Characteristics in Diagnosing and Predicting the Outcome of Sepsis and Its Treatment Result. Doctoral Thesis, Military Medical Academy.

[2] Nguyễn Thị Thu Hoài (2018) Evaluating the Relationship between Clinical Characteristics and Metabolic Disorders (Glucid, Lipid, Protid) at Dermatology Department, Thai Nguyen Central General Hospital. Science \& Technology, 89, 35-40.

[3] Barton, J.C. and Bertoli, L.F. (2012) Predictors of Shingles Reports at Diagnosis of Common Variable Immunodeficiency and Selective Immunoglobulin G Subclass Deficiency in 212 Alabama Adults. Infectious Disease Reports, 4, e34.

https://doi.org/10.4081/idr.2012.e34

[4] Campbell, T.M., McSharry, B.P., Steain, M., Ashhurst, T.M., Slobedman, B., et al. (2018) Varicella Zoster Virus Productively Infects Human Natural Killer Cells and Manipulates Phenotype. PLOS Pathogens, 14, e1006999. https://doi.org/10.1371/journal.ppat.1006999

[5] Cauda, R., Prasthofer, E.F., Tilden, A.B., Whitley, R.J. and Grossi, C.E. (1987) T-Cell Imbalances and NK Activity in Varicella-Zoster Virus Infections. Viral Immunology, 1, 145-152. https://doi.org/10.1089/vim.1987.1.145

[6] De Pelsmaeker, S., Romero, N., Vitale, M. and Favoreel, H.W. (2018) Herpesvirus Evasion of Natural Killer Cells. Journal of Virology, 92, e2105-17. https://doi.org/10.1128/JVI.02105-17

[7] Etzioni, A., Eidenschenk, C., Katz, R., Beck, R., Casanova, J.L., et al. (2005) Fatal Varicella Associated with Selective Natural Killer Cell Deficiency. The Journal of Pediatrics, 146, 423-425. https://doi.org/10.1016/j.jpeds.2004.11.022

[8] Gerada, C., Campbell, T.M., Kennedy, J.J., McSharry, B.P., Steain, M., et al. (2020) Manipulation of the Innate Immune Response by Varicella Zoster Virus. Frontiers in Immunology, 11, 1. https://doi.org/10.3389/fimmu.2020.00001

[9] Ihara, T., Kamiya, H., Starr, S.E., Arbeter, A.M. and Lange, B. (1989) Natural Killing of Varicella-Zoster Virus (VZV)-Infected Fibroblasts in Normal Children, Children with VZV Infections, and Children with Hodgkin's Disease. Acta Paediatrica Japonica, 31, 523-528. https://doi.org/10.1111/j.1442-200X.1989.tb01349.x 
[10] Kim, C.K., Choi, Y.M., Bae, E., Jue, M.S., So, H.S., et al. (2018) Reduced NK Cell IFN-Gamma Secretion and Psychological Stress Are Independently Associated with Herpes Zoster. PLoS ONE, 13, e0193299. https://doi.org/10.1371/journal.pone.0193299

[11] Laing, K.J., Ouwendijk, W.J.D., Koelle, D.M. and Verjans, G (2018) Immunobiology of Varicella-Zoster Virus Infection. The Journal of Infectious Diseases, 218, S68-S74. https://doi.org/10.1093/infdis/jiy403

[12] Patton, K.T. (2015) Support and Movement. In: Anatomy and Physiology, Elsevier Health Sciences, Amsterdam, 202.

[13] See, D.M., Khemka, P., Sahl, L., Bui, T. and Tilles, J.G. (1997) The Role of Natural Killer Cells in Viral Infections. Scandinavian Journal of Immunology, 46, 217-224. https://doi.org/10.1046/j.1365-3083.1997.d01-121.x

[14] Vossen, M.T., Biezeveld, M.H., de Jong, M.D., Gent, M.R., Baars, P.A., et al. (2005) Absence of Circulating Natural Killer and Primed CD8+ Cells in Life-Threatening Varicella. The Journal of Infectious Diseases, 191, 198-206. https://doi.org/10.1086/426866

[15] Wolff, K. and Johnson, R.A. (2009) Herpes Zoster. In: Color Atlas \& Synopsis of Dermatology, 6th Edition, McGraw Hill, London, 837-845.

[16] Arvin, A.M. (2008) Humoral and Cellular Immunity to Varicella-Zoster Virus: An Overview. The Journal of Infectious Diseases, 197, S58-S60.

https://doi.org/10.1086/522123 